\title{
Titanium Alloy is Best Material for Roller Shaft in Sugar Mill
}

\author{
Ashish B. Pendharkar, Laxmikant S. Dhamande
}

\begin{abstract}
In sugar industry, the sugar processing done in different sections, but to increase total crushing per day (TCD) capacity, the milling section takes a vital role in the sugar industry. The sugar industry aims to extract the maximum amount of juice from sugarcane. In the milling section, the processed sugarcane is fed in between the three-roller shaft from the different arrangements, there are different loads applied on each part roller shafts. When load between all rollers varies then there is a chance of bending it is analyzed to check the roller shaft condition. The modeling is done on roller shaft with the help of CATIA V5. After modeling, we analyze the condition of the rollers, when different stress or forces are applied to different sections of the roller shaft it analyzed with the help of Finite element method using ANSYS WORKBENCH software. We were selecting titanium alloy materials for the roller shaft to analyze the variation in results. When comparing the calculated and software-based results using Maximum Shear stress and Total deformation for top, feed, and discharge rollers said the roller shafts are safe to use in the sugar industry and titanium alloy is the best material for these roller shafts.
\end{abstract}

Keywords: Three Rollers, Modelling, Static Analysis, Maximum shear stress, Total Deformation, ANSYS WORKBENCH.

\section{INTRODUCTION}

In India, sugarcane is that the basic material for sugar industry this sugar is produced from sugarcane juice and waste bagasse is employed for power generation for boiler and remaining raw bagasse is generally used for manufacturing of paper or cardboard generation of electricity ethanol and pellets. Thus, sugar industries are one of the main components of the Indian economy and contribute significantly to the socio-economic development of the state further in India. The Maharashtra is the leading states contributing $35 \%$ of the entire sugar production within the country. Within the Sugar Industry, a cane transfer from one position to a different with the assistance of a cane carrier, which may transfer processed sugarcane to preparatory devices like cutter, leveler, and shredder, the processed

Manuscript received on August 07, 2021.

Revised Manuscript received on October 04, 2021.

Manuscript published on October 30, 2021.

* Correspondence Author

Ashish B. Pendharkar*, M.Tech. Student, Department of Mechanical Affiliated to Savitribai Phule Pune University, Pune, (Maharashtra), India. E-mail: ashishpendharkar210896@gmail.com

Laxmikant S. Dhamande, Associate Professor, SRES's Sanjivan College of Engineering, Kopargoan, affiliated to Savitribai Phule Pune University, Pune, (Maharashtra), India.

(CThe Authors. Published by Blue Eyes Intelligence Engineering and BY-NC-ND license (http://creativecommons.org/licenses/by-nc-nd/4.0/) Engineering, SRES's Sanjivani College of Engineering, Kopargoan, Sciences Publication (BEIESP). This is an open access article under the CC

sugarcane is removed into small pieces and fed into the milling roller to extract the juice. The remaining staff of this sugarcane is named bagasse and this bagasse is employed as fuel for steam generation within the boilers. This steam is employed to rotate the turbine and this turbine is given the facility to rollers. The main motive of the sugar industry is to extract the most amount of juice from sugarcane. Differing types of roller mills arrangement are utilized in different industries like two high roller mills, three high roller mills, four high roller mills, and 6 high roller mills. Usually three roller mills setup is employed nowadays to extract juice from sugarcane within the sugar industry. It consists of top roller, feed roller and discharge rollers. The processed Sugarcane is being fed in between these three roller shafts. The roller shaft is split into eleven sections that are roller, two supports on both side of roller also there are four sections i.e. section 1 and section 2 of the shaft on both side of roller and two key arrangements is shown in Fig. 3. Section1 and section2 are two main parts of roller shafts where bearing and pinion are placed around them. This roller arranged in triangle arrangement is shown in Fig. 2.

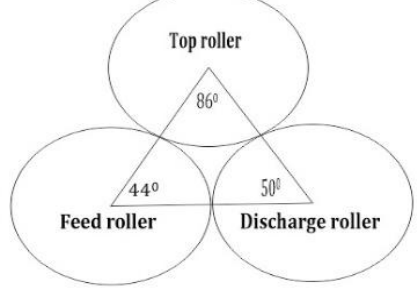

Fig. 1. Conventional 3 Roller Mill Arrangement

A fourth press-roller i.e. toothed roller pressure feeder is employed in industry, which can be accustomed to fed sugarcane to top and feed rollers to facilitate extraction. The top roller, feed roller and discharge roller shaft had shared about $50 \%, 15 \%$ and $35 \%$ torque. These all rollers have a high coefficient of friction and these rollers rotated with the assistance of a turbine. Using these three roller shafts we extract sucrose up to $96-97 \%$. These three rollers are carried on heavy shafts running in their bearing and it's placed in a very casing, which is bolted on a bedplate. These heavy cast steel frames referred to as mill housing and bearings are supported in sugar mill headstocks during which rollers rotate at various speeds. Where hydraulic pressure is applied to those bearing vertically downward to the highest roller and exerts constant pressure there on. The pressure developed during milling depends on the layer of bagasse which can be placed in between these rollers. The rollers are arranged in a isosceles triangular arrangement with a top angle, feed angle and discharge angle is $86^{0}, 44^{\circ} \& 50^{\circ}$ respectively from the vertical below the top roller is shown in fig.2. The $50 \%$ of mill torque acted on the top roller.

Published By:

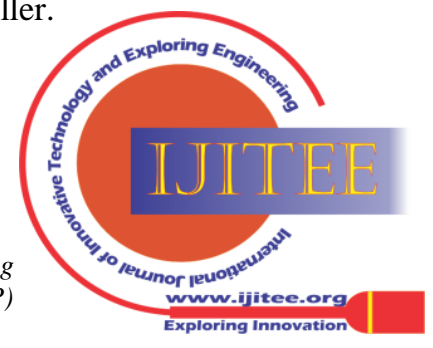


The Sugar industry should simple structural arrangement with maximum production capability, which helps to form a profit for the industry. With the assistance of the analytical and finite element method, we calculate maximum shear stress and total deformation with the assistance of various materials for roller shafts and test which material is suitable for roller shafts to enhance roller shafts conditions.

\section{METHODOLOGY}

\section{A. Analytical Calculations:}

Because of nature of continuous live loads acting on roller shafts, it makes roller as statically indeterminate structure to observe roller shafts conditions.

B. Modeling:

To prepare Models of Roller shaft using modeling software that is CATIA V5.

C. FEA Analysis: conditions using ANSYS WORKBENCH software

D. Result Evaluation:

Analytical calculation and ANSYS WORKBENCH results for maximum shear stress and total deformation value is compared by using different material for roller shafts to find out which material is best for roller shafts.

\section{MODELING}

CATIA V5 is used for designing, simulation, and analysis of the. All three roller shafts have the same dimension and their model is shown below:

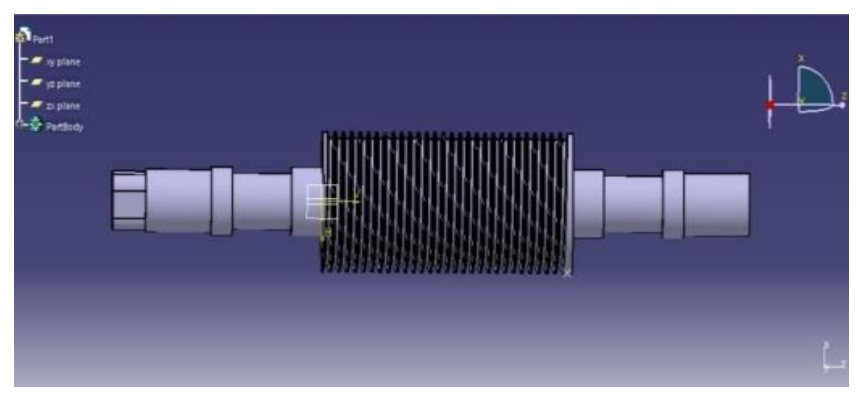

Fig. 2. Three-dimensional model of roller

\section{THEORETICAL STATIC STRUCTURAL ANALYSIS}

In milling section, Top roller rotates with the help of steam turbine at speed of $6 \mathrm{rpm}$. Near about $50 \%$ of milling torque applied on top roller. While analyzing problem load is divided into two components that is horizontal load and vertical load and top roller is made up of forged steel material.

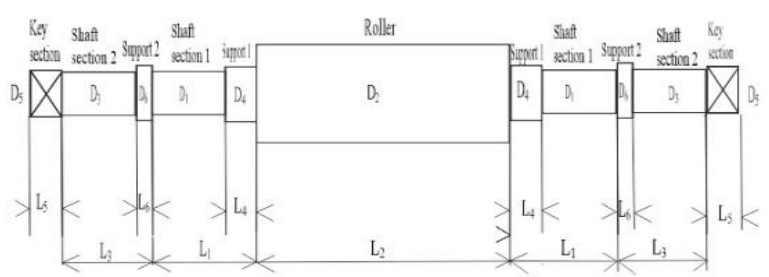

Fig. 3. Side view of roller mill shaft

Rollers Shaft inputs data are as follows:

$D_{1}, D_{2}, D_{3}, D_{4}, D_{5}, D_{6}$ is diameter of shaft section 1 , roller, shaft section 2, support 1, key section and support 2 .
The analysis is completed using given material load

$\mathrm{L}_{1}, \mathrm{~L}_{2}, \mathrm{~L}_{3}, \mathrm{~L}_{4}, \mathrm{~L}_{5}, \mathrm{~L}_{6}$ is length of shaft section1, roller, shaft section 2, support 1 , key section and support 2 .

$\mathrm{D}_{1}=305 \mathrm{~mm}, \mathrm{D}_{2}=762 \mathrm{~mm}, \mathrm{D}_{3}=340 \mathrm{~mm}, \mathrm{D}_{4}=370.5 \mathrm{~mm}$, $\mathrm{D}_{5}=200 \mathrm{~mm}, \mathrm{D}_{6}=370.5 \mathrm{~mm}$

$\mathrm{L}_{1}=550 \mathrm{~mm}, \mathrm{~L}_{2}=1524 \mathrm{~mm}, \mathrm{~L}_{3}=400 \mathrm{~mm}$ and $\mathrm{L}_{4}=190 \mathrm{~mm}$,

$\mathrm{L}_{5}=200 \mathrm{~mm}, \mathrm{~L}_{6}=130 \mathrm{~mm}$

P.C.D of pinion $=\mathrm{d}=741 \mathrm{~mm}$,

$\mathrm{L}=2 \mathrm{~L}_{1}+\mathrm{L}_{2}=2624 \mathrm{~mm}$,

Power on top roller shaft $(\mathrm{p})=450 \mathrm{kw}$,

Top roller shaft speed $(\mathrm{n})=5.8 \mathrm{rpm}$,

Drive torque $=\frac{p * 9.55}{n}=740.9 \mathrm{KNm}$

\section{A. Theoretical analysis of Top roller:}

Shaft is made up of forged steel material and near about $50 \%$ of torque is taken by top roller is,

$\tau_{\text {top }}=370.4 \mathrm{KNm}$

Force acting on horizontal component=

$\mathrm{F}_{\mathrm{ph}}=\frac{\text { Drive torque on top roller }}{d / 2}=1000 \mathrm{KN}$

Force acting on vertical component=

$\mathrm{F}_{\mathrm{pv}}=\tau_{\mathrm{top}} \cos \Theta=266.155 \mathrm{KN}$

Diameter of hydraulic Ram $=\mathrm{d}_{\mathrm{h}}=320 \mathrm{~mm}$,

Oil pressure $=\mathrm{P}_{\text {oil }}=1.72 \mathrm{Kg} / \mathrm{mm}^{2}$

Total hydraulic load on each bearing=

$\mathrm{F}_{\mathrm{h}}=$ Area of piston $* \mathrm{P}_{\text {oil }}=1383.3 \mathrm{KN}$

Total 8 ton weight of top, feed and discharge roller shaft is acting vertical downward.

4.1.1Vertical and horizontal loading diagram:

Resultant of horizontal and vertical loading:-

$\mathrm{R}_{\mathrm{A}}=\sqrt{R a v^{2}+R a h^{2}}=1301.9 \mathrm{KN}$

$\mathrm{R}_{\mathrm{G}}=\sqrt{R g v^{2}+R g h^{2}}=1069.8 \mathrm{KN}$

Resultant bending moment at mid-point of roller=

$\mathrm{M}=\sqrt{B M v^{2}+B M h^{2}}=853.229 * 10^{3} \mathrm{KNmm}$

Resultant torsional Moment $=\mathrm{T}=\frac{16 \mathrm{Mt}}{\pi \mathrm{d}^{3}}=1.056 * 10^{7} \mathrm{KNmm}$

4.1.1.2. Maximum shear stress:-

According to maximum shear stress theory for top roller shaft is,

$\left.T_{\max }=\frac{16}{\pi \mathrm{d}^{3}} \sqrt{\mathrm{M}^{2}+\mathrm{T}^{2}}\right)=121.94 \mathrm{Mpa}$

(For Forged steel material, $S_{s y}=0.5 * 380=190 \mathrm{Mpa}>T_{\max }$ )

Therefore top roller shaft is safe according to maximum shear stress theory.

\section{B. Theoretical analysis for Feed roller:}

Geometry is similar like top roller and it is made up of forged steel material and near about $15 \%$ of torque is taken by feed roller, So

$\tau_{\text {feed }}=111.135 \mathrm{KNm}$

Force acting on horizontal component $=\mathrm{F}_{\mathrm{ph}}=299.9 \mathrm{KN}$ Force acting on vertical component $=\mathrm{F}_{\mathrm{pv}}=208.736 \mathrm{KN}$ The total vertical load acting on the roller $=1505.5 \mathrm{KN}$ The total horizontal load acting on the roller $=1465 \mathrm{KN}$ 4.2.1. Vertical and horizontal loading diagram:

4.2.1.1. Resultant reaction for horizontal and vertical loading:-

$\mathrm{R}_{\mathrm{A}}=\sqrt{R a v^{2}+R a h^{2}}=822,37 \mathrm{KN}$

$\mathrm{R}_{\mathrm{G}}=\sqrt{R g v^{2}+R g h^{2}}=1230.8 \mathrm{KN}$

Published By:

Blue Eyes Intelligence Engineering

and Sciences Publication (BEIESP)

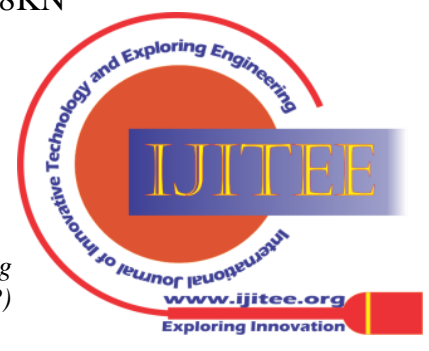


Resultant bending moment at mid-point of roller $=\mathrm{M}=$ $\sqrt{B M v^{2}+B M h^{2}}=1049.085 * 10^{3} \mathrm{KNmm}$

$\mathrm{T}=$ Torsional Moment $=16 \mathrm{M}_{\mathrm{t}} /\left(\pi^{3}\right)=3.839 * 10^{6} \mathrm{KNmm}$

According to maximum shear stress theory for feed roller shaft is,

Therefore feed roller shaft is safe according to maximum shear stress theory.

\subsection{Theoretical analysis for Discharge roller:}

Geometry similar like top roller and discharge roller is made up of forged steel and near about $35 \%$ of torque is taken by discharge roller shaft.

$\tau_{\text {discharge }}=260 \mathrm{KNm}$

Force acting on vertical component $=\mathrm{F}_{\mathrm{pv}}=199.17 \mathrm{KN}$

The total vertical load acting on the roller $=1505.5 \mathrm{KN}$

The total horizontal load acting on the roller= $1465.09 \mathrm{KN}$

4.3.1. Vertical and horizontal loading diagram:

4.3.1.1. Resultant reactions for horizontal and vertical loading:

$\mathrm{R}_{\mathrm{A}}=\sqrt{R a v^{2}+R a h^{2}}=686.45 \mathrm{KN}$

$\mathrm{R}_{\mathrm{G}}=\sqrt{R g v^{2}+R g h^{2}}=1551.7 \mathrm{KN}$

Resultant bending moment at mid-point of roller=

$\mathrm{M}=1473.17 * 10^{3} \mathrm{KNmm}$

$\mathrm{T}=$ Torsional Moment $=5.375 * 10^{6} \mathrm{KNmm}$

4.3.1.2. Maximum shear stress:

According to maximum shear stress theory for discharge roller shaft is,

$T_{\max }=63.386 \mathrm{MPa}$

Therefore discharge roller shaft is safe according to maximum shear stress theory.

\section{FINITE ELEMENT ANALYSIS USING ANSYS WORKBENCH}

The Finite Element Analysis (FEA) is a numerical procedure for the analysis of complicated shapes. In this method, the geometrical model is divided into a small area called elements. Each element is connected by some nodes. Each node is having some degree of freedom. Based on the number of nodes, degrees of freedom, material properties element stiffness matrix is generated for each element. Finite Element Analysis or FEA is the simulation of a physical phenomenon using a numerical mathematical technique referred to as the Finite Element Method..

\section{A. Finite element analysis of top roller:}

a. Mesh Generation of top roller:

Meshing is performed in the ANSYS WORKBENCH software and size of is $10 \mathrm{~mm}$ and near about 334760 elements and 497480 nodes are obtained after meshing.

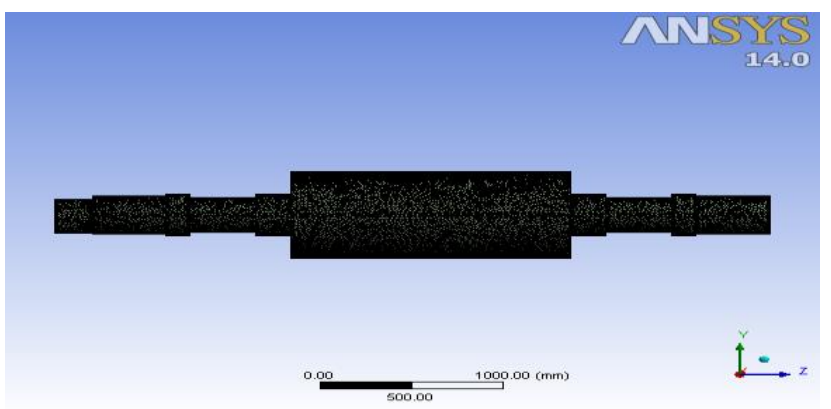

Fig. 2. Meshing of Model of roller for top roller 4.2.1.2. Maximum shear stress:-

$T_{\max }=45.814 \mathrm{Mpa}$

Force acting on horizontal component $=\mathrm{F}_{\mathrm{ph}}=700 \mathrm{KN}$

b. Loading and boundary conditions:

Horizontal and vertical load acted on feed roller is,

Total vertical load= $1360.32 \mathrm{KN}$ (up),

Total horizontal load= 661.7 KN (left)

The Tangential and Radial load at pinion end roller shaft is, Tangential Component $=1000 \mathrm{KN}$,

Radial Component $=266.155 \mathrm{KN}$

Hydraulic load is applied at the each bearing position is 1383.3KN and Standard earth gravity is applied.

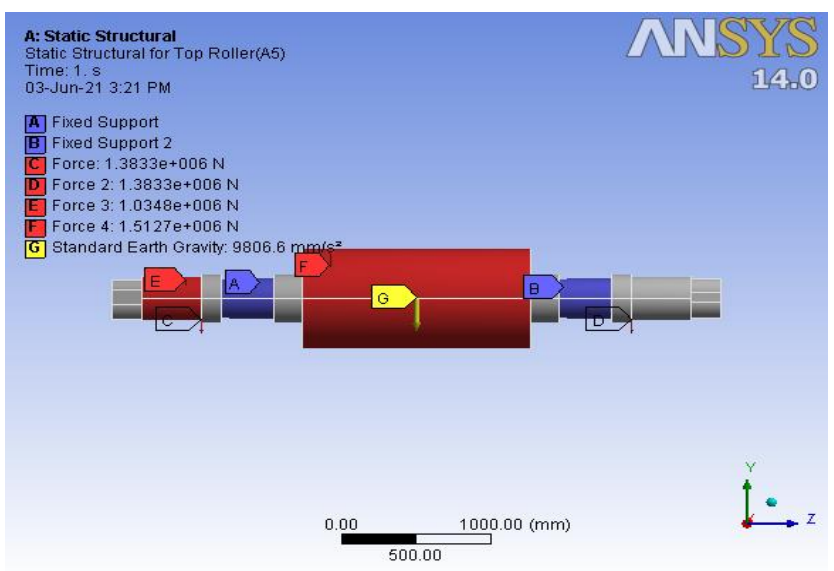

Fig.3. Loading and boundary condition details

c. Finite analysis of top rollers for forged steel material:

Table 1. Material properties of forged steel.

\begin{tabular}{|c|c|c|}
\hline Material Properties & Value & Unit \\
\hline Density & 7850 & $\mathrm{Kg} / \mathrm{m} 3$ \\
\hline Young Modulus & $2 \mathrm{e}+11$ & $\mathrm{~Pa}$ \\
\hline Poisson's ratio & 0.3 & - \\
\hline Bulk Modulus & $1.66 \times 10^{11}$ & $\mathrm{~Pa}$ \\
\hline Shear Modulus & $7.6923 \times 10^{10}$ & $\mathrm{~Pa}$ \\
\hline Tensile yield strength: & $2.5 \times 10^{8}$ & $\mathrm{~Pa}$ \\
\hline Compressive yield strength & $2.5 \times 10^{8}$ & $\mathrm{~Pa}$ \\
\hline Tensile ultimate strength & $4.6 \times 10^{8}$ & $\mathrm{~Pa}$ \\
\hline
\end{tabular}

d. Results for top roller shaft:

Maximum shear stress and total deformation for top roller using ANSYS WORKBENCH are shown in below figures,

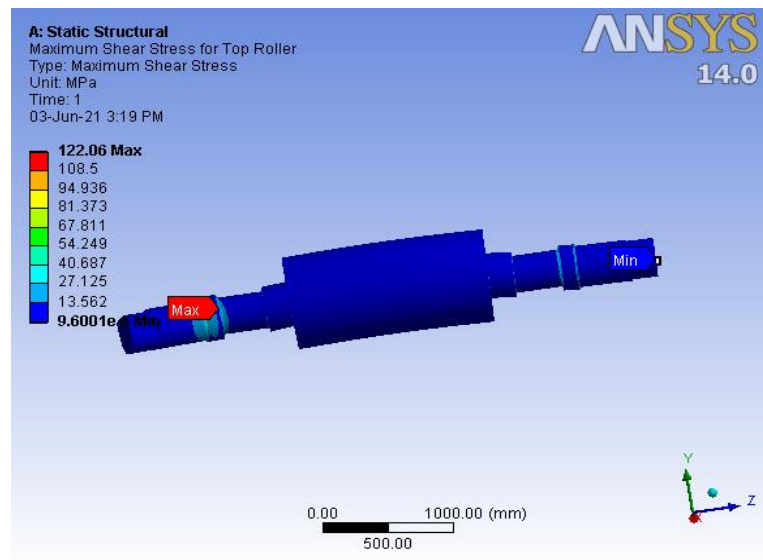

Fig.4. Maximum shear stress of top roller for forged steel

Published By:

Blue Eyes Intelligence Engineering and Sciences Publication (BEIESP)

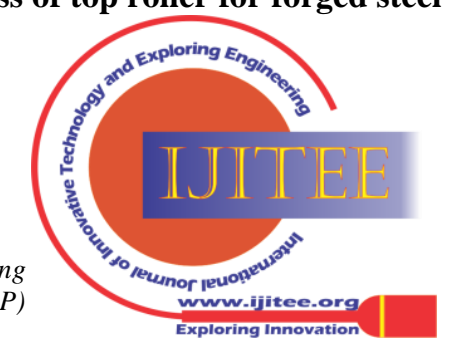




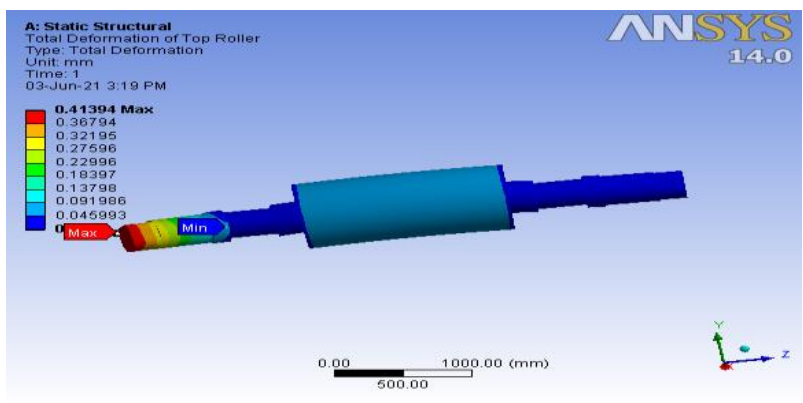

Fig.5. Total deformation of top roller for forged steel

Maximum shear stress is $122.08 \mathrm{MPa}$ which is at bearing position of top roller. Maximum value of shear stress is within limit, so shaft is safe to use. The minimum value of shear stress is $9.60 \mathrm{e}-5 \mathrm{MPa}$ at bearing, shell and pinion on other end and Maximum value of total deformation is 0.4139 $\mathrm{mm}$ at the pinion end of top roller shaft and Minimum value of total deformation is $0 \mathrm{~mm}$ which occur were bearing is placed on roller shaft.

\section{B. Finite element analysis of feed roller:}

a. Mesh Generation of feed roller:

Mesh generating pattern is similar to top roller.

b. The material used of feed roller:

Forged steel material used for feed roller and materials

property is similar like a top roller.

c. Loading and Boundary conditions:

Horizontal and vertical load acted on feed roller is,

Total vertical load= $1504.6 \mathrm{KN}$ (down),

Total horizontal load= $1465 \mathrm{KN}$ (right)

The Tangential and Radial load at pinion end roller shaft is, Tangential Component $=299.9 \mathrm{KN}$,

Radial Component $=208.73 \mathrm{KN}$

Standard earth gravity (self-weight is applied)

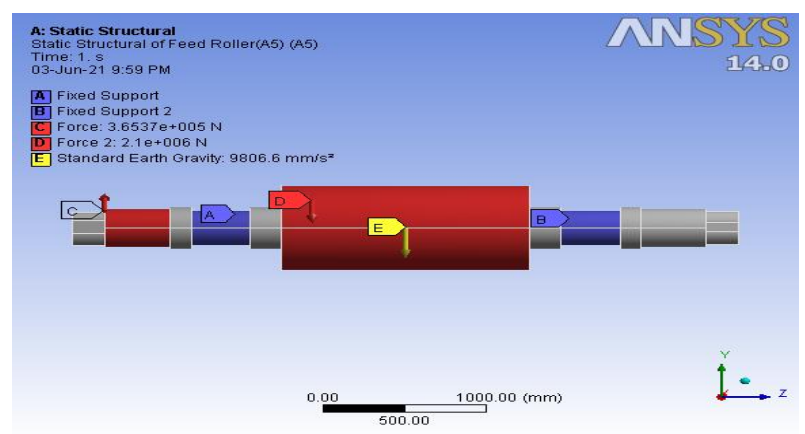

Fig.6. Loading and boundary condition details for Feed Roller

d. Results for feed roller shaft:

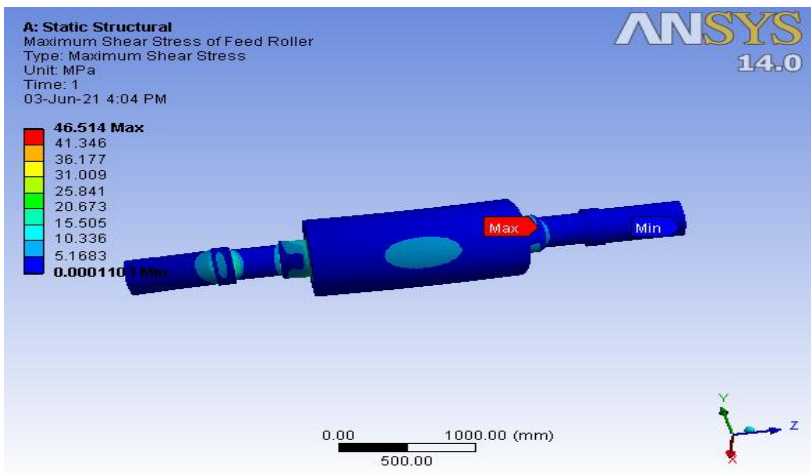

Fig.7. Maximum Shear Stress of feed roller for forged steel

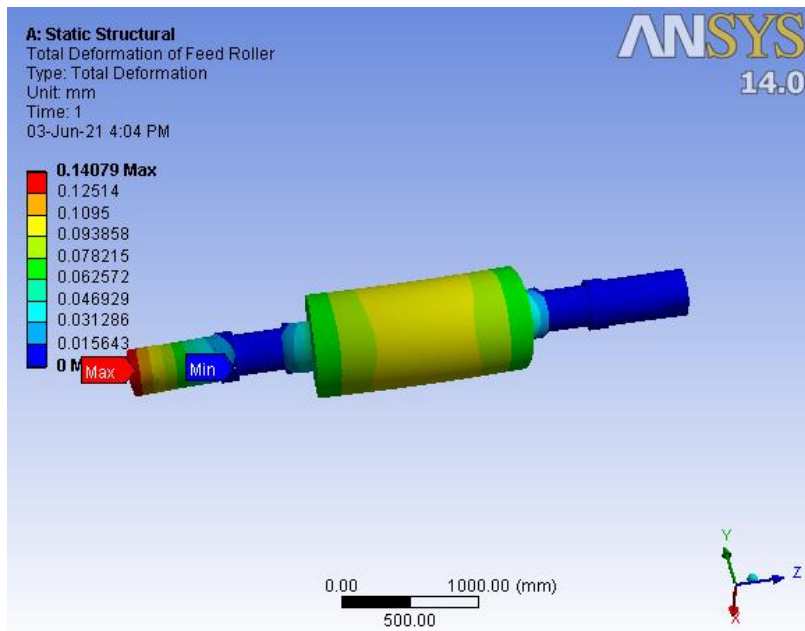

Fig. 8. Total deformation of Feed roller for forged steel

Maximum shear stress is $46.51 \mathrm{MPa}$ and this result is within the limit so the feed roller shaft is safe to use. The minimum value of shear stress is $0.0001103 \mathrm{MPa}$ at bearing, shell, and pinion end and the

Similarly, Maximum value of total deformation is 0.14079 $\mathrm{m}$ at the pinion end of feed roller and the minimum value of deformation is $0 \mathrm{~mm}$ which is at bearing position.

\section{Finite element Analysis of Discharge Roller:}

a. Mesh Generation: Mesh generating pattern is similar to top roller.

b. The material used of Discharge roller:

Forged steel material used for feed roller and materials property is same as a top roller.

c. Loading and Boundary conditions:

Horizontal and vertical load acted on feed roller is,

Total vertical load= $1505.5 \mathrm{KN}$ (down),

Total horizontal load= $1548.99 \mathrm{KN}$ (right)

The Tangential and Radial load at pinion end roller shaft is,

Tangential Component $=700 \mathrm{KN}$,

Radial Component $=199.17 \mathrm{KN}$

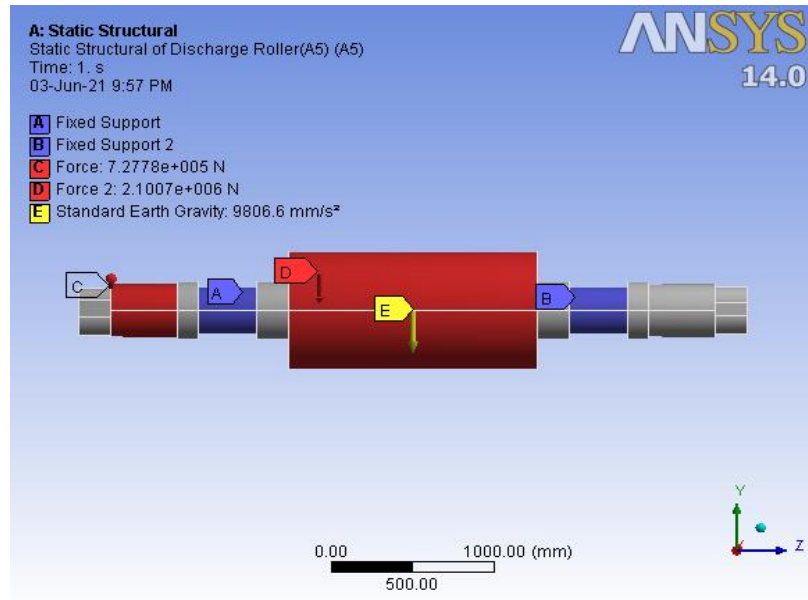

Fig. 9. Loading and boundary condition details for Discharge Roller

d. Results for discharge roller shaft:

Published By:

Blue Eyes Intelligence Engineering

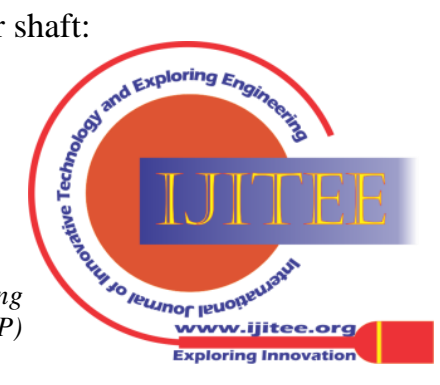




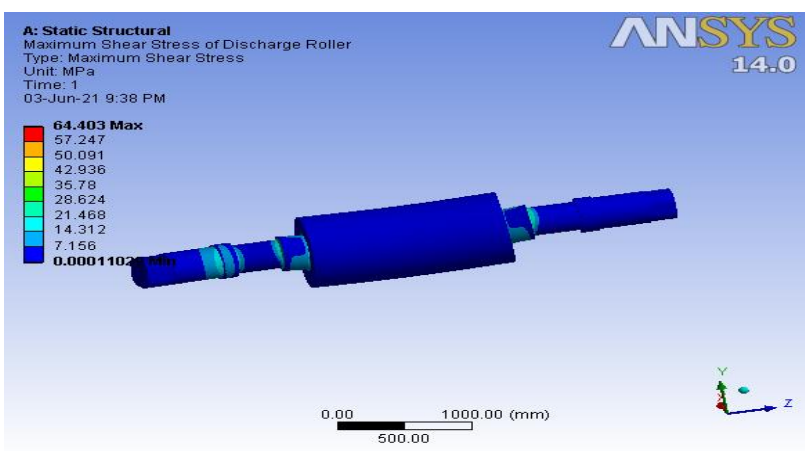

Fig. 10. Maximum Shear Stress of discharge roller for forged steel

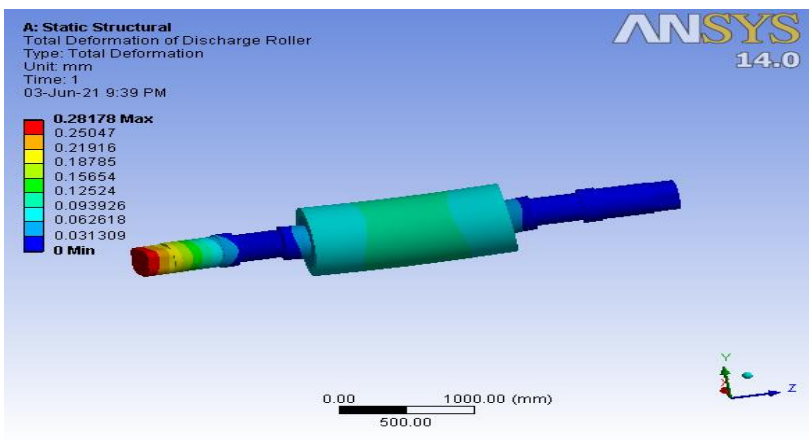

Fig. 11. Total deformation of Discharge roller for forged steel

Maximum shear stress is $64.403 \mathrm{MPa}$ and this results are within the limit so the discharge shaft is safe to use. The minimum value of shear stress is $0.00011 \mathrm{MPa}$ at bearing, shell, and pinion end and the

Similarly, Maximum total deformation is $0.028178 \mathrm{~m}$ at the pinion end of feed roller and the minimum value of deformation is $0 \mathrm{~mm}$ which is at the bearing position.

\section{USING DIFFERENT MATERIAL FOR ROLLER SHAFTS TO IDENTIFY VARIATION IN RESULTS}

The rollers are actually made of forged steel but to analyzing its effect, we will use different materials for roller shafts to get the best results. In the sugar industry, the load acted in between three rollers is dynamic, and this load varies due to a load of crushing sugarcane. When roller shaft is safe for static analysis, but it is not same for dynamical analysis. Hence, we need to get the best results for roller shafts to avoid this effect on roller shafts. Hence, we need to check maximum shear stress and total deformation using a different material for roller shafts and this is done using ANSYS WORKBENCH is shown below:

Table 2. Maximum shear stress and deformation for top roller shaft.

\begin{tabular}{|c|c|c|c|c|c|c|}
\hline \multicolumn{7}{|c|}{ Top Roller Shaft } \\
\hline Material & $\begin{array}{c}\text { Alumin } \\
\text { um } \\
\text { alloy }\end{array}$ & $\begin{array}{c}\text { Grey } \\
\text { cast } \\
\text { iron }\end{array}$ & $\begin{array}{c}\text { Copper } \\
\text { alloy }\end{array}$ & $\begin{array}{c}\text { Magn } \\
\text { esium } \\
\text { alloy }\end{array}$ & $\begin{array}{c}\text { Titaniu } \\
\text { m alloy }\end{array}$ & $\begin{array}{c}\text { Stainless } \\
\text { steel }\end{array}$ \\
\hline $\begin{array}{c}\text { Maximu } \\
\text { m Shear } \\
\text { Stress, } \\
\text { MPa }\end{array}$ & 119.69 & $\begin{array}{c}123 . \\
73\end{array}$ & 119.18 & $\begin{array}{c}118.3 \\
5\end{array}$ & 117.8 & 121.28 \\
\hline $\begin{array}{c}\text { Total } \\
\text { Deformat } \\
\text { ion, mm }\end{array}$ & 1.1591 & 0.75 & 0.7477 & $\begin{array}{c}1.820 \\
9\end{array}$ & 0.8521 & 8 \\
\hline
\end{tabular}

Table 3. Maximum shear stress and deformation for feed roller shaft.

\begin{tabular}{|c|c|c|c|c|c|c|}
\hline \multicolumn{7}{|c|}{ Feed Roller Shaft } \\
\hline Material & $\begin{array}{c}\text { Alumin } \\
\text { um } \\
\text { alloy }\end{array}$ & $\begin{array}{c}\text { Grey } \\
\text { cast } \\
\text { iron }\end{array}$ & $\begin{array}{c}\text { Copper } \\
\text { alloy }\end{array}$ & $\begin{array}{c}\text { Magn } \\
\text { esium } \\
\text { alloy }\end{array}$ & $\begin{array}{c}\text { Titaniu } \\
\text { m alloy }\end{array}$ & $\begin{array}{c}\text { Stainless } \\
\text { steel }\end{array}$ \\
\hline $\begin{array}{c}\text { Maximu } \\
\text { m Shear } \\
\text { Stress, } \\
\text { MPa }\end{array}$ & 44.927 & $\begin{array}{c}47.4 \\
72\end{array}$ & 45.042 & $\begin{array}{c}44.16 \\
9\end{array}$ & 44.134 & 46.083 \\
\hline $\begin{array}{c}\text { Total } \\
\text { Deformat } \\
\text { ion, mm }\end{array}$ & $\begin{array}{c}0.3971 \\
5\end{array}$ & $\begin{array}{c}0.25 \\
677\end{array}$ & $\begin{array}{c}0.2541 \\
4\end{array}$ & $\begin{array}{c}0.624 \\
8\end{array}$ & 0.2911 & 0.14571 \\
\hline
\end{tabular}

Table 4. Maximum shear stress and deformation for discharge roller shaft.

\begin{tabular}{|c|c|c|c|c|c|c|}
\hline \multicolumn{7}{|c|}{ Discharge Roller Shaft } \\
\hline Material & $\begin{array}{c}\text { Alumi } \\
\text { num } \\
\text { alloy }\end{array}$ & $\begin{array}{c}\text { Grey } \\
\text { cast } \\
\text { iron }\end{array}$ & $\begin{array}{c}\text { Copper } \\
\text { alloy }\end{array}$ & $\begin{array}{c}\text { Magn } \\
\text { esium } \\
\text { alloy }\end{array}$ & $\begin{array}{c}\text { Titaniu } \\
\text { m alloy }\end{array}$ & $\begin{array}{c}\text { Stainless } \\
\text { steel }\end{array}$ \\
\hline $\begin{array}{c}\text { Maximum } \\
\text { Shear } \\
\text { Stress, } \\
\text { MPa }\end{array}$ & 64.30 & 64.67 & 64.209 & $\begin{array}{c}64.10 \\
4\end{array}$ & 63.987 & 64.474 \\
\hline $\begin{array}{c}\text { Total } \\
\text { Deformati } \\
\text { on, mm }\end{array}$ & 0.791 & 0.514 & 0.5101 & 1.244 \\
2 & 7 & 2 & 3 & 0.5819 & 0.29228 \\
\hline
\end{tabular}

While analyzing, the best material to be used for roller shaft is Titanium alloy.

\section{RESULT AND DISCUSSION}

The main motive of the sugar industry is to extract the maximum amount of juice from sugarcane, When the load between all rollers varies then there is a chance to bend the roller shaft assembly, to avoid this bending we will analyze the roller shaft condition. To avoid this failure, we will analyze roller shaft conditions. When different stress or forces are applied to different sections of the roller shaft with the help of Finite element methods, and we can calculate the maximum shear stress and total deformation on the roller shaft using Ansys Workbench software. While analyzing, the maximum shear stress for calculated and software (Using ANSYS WORKBENCH) values for roller shaft using forged steel material are nearly equal. Static structura analysis of all three rollers is done for different materials is,

Table 5. Maximum shear stress for different material.

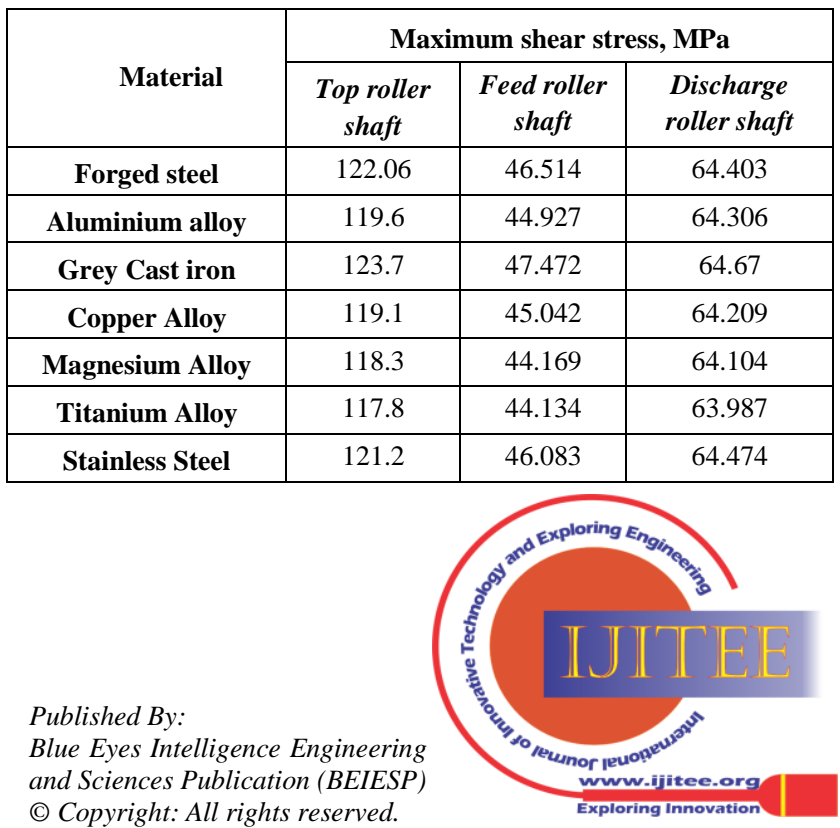


Titanium Alloy is Best Material for Roller Shaft in Sugar Mill

Table 6. Total Deformation for different material.

\begin{tabular}{|c|c|c|c|}
\hline \multirow{2}{*}{ Material } & \multicolumn{3}{|c|}{ Total Deformation, mm } \\
\cline { 2 - 4 } & $\begin{array}{c}\text { Top roller } \\
\text { shaft }\end{array}$ & $\begin{array}{c}\text { Feed roller } \\
\text { shaft }\end{array}$ & $\begin{array}{c}\text { Discharge } \\
\text { roller shaft }\end{array}$ \\
\hline Forged steel & 0.41394 & 0.14079 & 0.28178 \\
\hline Aluminium alloy & 1.1591 & 0.39715 & 0.79187 \\
\hline Grey Cast iron & 0.7541 & 0.25677 & 0.5147 \\
\hline Copper Alloy & 0.7477 & 0.2541 & 0.51012 \\
\hline Magnesium Alloy & 1.8209 & 0.6248 & 1.2443 \\
\hline Titanium Alloy & 0.8521 & 0.2911 & 0.5819 \\
\hline Stainless Steel & 0.4283 & 0.1457 & 0.29228 \\
\hline
\end{tabular}

While analyzing we say, The maximum shear stress and total deformation result for all three roller shafts for titanium alloy are lesser than compare to other materials, and it is useful for the sugar industry to improve the lifespan and performance of roller shafts. Hence, titanium alloy is the best material to be used for roller shafts.

\section{CONCLUSION}

Using static structural analysis, Maximum shear stress results for roller shafts is less than yield strength value and analytical calculations and software based results are nearly identical, so results are validated for forged steel material so roller shafts is safe to used. As per our results, titanium alloy is the best materials, and using this material we optimize structure of roller shaft.

\section{REFERENCES}

1. Sheetal, Kumar R. Rethinking on growth mechanism of Indian sugar industry. Journal of Asia Business Studies 2019;13:412-432

2. Sawhney DM. The Indian sugar industry. Zuckerindustrie.Sugar.Industry 2002;127:186-194.

3. Solomon S. Sugarcane production and development of sugar industry in India. Sugar Tech 2016;18:588-602.

4. Randhawa G, Gupta A. Present status and challenges of sugar industry in Punjab. Prajnan 2014;42:375-391.

5. Varshney D, Mandade P, Shastri Y. Multi-objective optimization of sugarcane bagasse utilization in an Indian sugar mill. Sustainable Production and Consumption 2019;18:96-114.

6. Uygan D, Cetin O, Alveroglu V, Sofuoglu A. Improvement of water saving and economic productivity based on quotation with sugar content of sugar beet using linear move sprinklet irrigation. Agricultural Water Management 2021;255:106989.

7. Mubarak MU, Zahir M, Ahmad S, Wakeel A. Sugar beet yield and industrial sugar contents improved by potassium fertilization under scarce and adequate moisture conditions. Journal of Integrative Agriculture 2016;15:2620-2626.

8. Prada M, Godinho CA, Garrido MV, Rodrigues DL, Coelho I, Lopes D. A qualitative study about college students attitudes, knowledge and perceptions regarding sugar intake. Appetite 2021;159:105059.

9. Kakade A, Sudeep Ingole S, Bhatt DV, Menghani J. Tribological behavior of sugar mill roller shaft in laboratory simulated condition. Wear 2013;302:1568-1572.

10. Pater Z., Tomczak J, Bulzak T. Problems of forming stepped axles and shafts in a 3-roller skew rolling mill. Journal of Materials Research and Technology 2020;9:10434-10446.

11. Hou Y, Wang X. Measurement of load distribution in a cylindrical roller bearing with an instrumented housing: Finite element validation and experimental study. Tribology International 2021;155:106785.

12. kakade A, Ingole S, Bhatt DV, Menghani JV. Tribochemistry of Sugar Mill Roller Shaft Materials, Material todays: proceedings 2017;4:434-441.

13. Dalvi SD, Chandrababu HD, Satav S, Vijoykumar. Failure analysis of a carbon steel roller shaft of continuous pad steam machine. Engineering failure analysis 2017;9:118-128.

14. E.E.T. ELSawy, M.R. EL-Hebeary, I.S.E. El Mahallawi. Effect of manganese, silicon and chromium additions on microstructure and wear characteristics of grey cast iron for sugar industries applications. Wear 2017;390-391:113-124.

15. V.B. Bhandari, "Design of machine element, Tata McGraw Hill publications".

16. E.Hugot, "Handbook of cane sugar engineering third edition", Elsevier science publishers, 1986.

17. ANSYS workbench help.

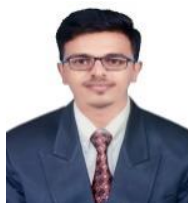

\section{AUTHORS PROFILE}

Ashish B. Pendharkar, M. Tech. (Design Engineering), SRES's Sanjivani college of engineering, Kopargoan, Savitribai Phule University, Pune, Maharashtra, India Ashishpendharkar210896@gmail.com

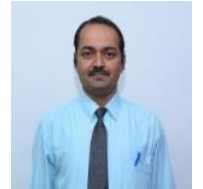

Laxmikant S. Dhamande, Ph.D. Mechanica engineering, $16+$ years of teaching experience, 15+ Paper published, 21+ Paper presented in Conference, Associate Professor, SRES's Sanjivani college of engineering, Kopargoan, Savitribai Phule University, Pune, Maharashtra, India
Published By:

Blue Eyes Intelligence Engineering and Sciences Publication (BEIESP)

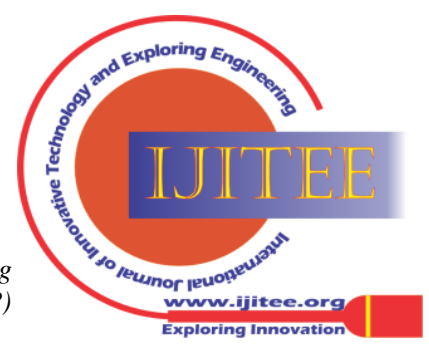

